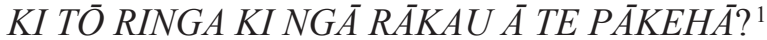 \\ DRAWINGS AND SIGNATURES OF MOKO BY MĀORI IN \\ THE EARLY 19TH CENTURY
}

\author{
NGĀRINO ELLIS (Ngāpuhi, Ngāti Porou) \\ University of Auckland
}

\author{
Ko Rākaumangamanga te maunga, \\ Ko Ipipiri te moana, \\ Ko Te Rāwhiti te marae, \\ Ko Ngāti Kuta te hapū, \\ Ko Ngāpuhi te iwi, \\ Ko Te Nana te tupuna, \\ Ko Ngā Taiapa Rino o Te Poka o Whata Paraua ahau. \\ Rākaumangamanga is my mountain, \\ Ipipiri is my sea, \\ Te Rāwhiti is my marae, \\ Ngāti Kuta is my sub-tribe, \\ Ngāpuhi is my tribe, \\ Te Nana is my ancestor, \\ Ngā Taiapa Rino o Te Poka o Whata Paraua (Ngārino) is my name.
}

In May 2013, on a beautiful Monday morning, around 150 members of hapu 'sub-tribes' from around the Bay of Islands, including Ngāti Manu and Te Kapotai and the two hapu of Te Rawhiti (Ngāti Kuta and Patu Keha), boarded a hired ferry at Opua. Along with members of the Waitangi Tribunal and their retinue, the group visited sacred and important hapu sites. We began on our precious moana 'ocean' and ended up travelling by bus inland to marae 'ancestral community hubs' at Waikare and Karetu. This was to be a historic moment as we heard from our kuia 'female elders' and kaumàtua 'male elders' about the effects of Te Tiriti o Waitangi (the Treaty of Waitangi) 1840 and its insidious legacies for us today. The next day our kaikōrero 'speakers' began four days of hearings, in which they frequently referred to documents which our tüpuna 'ancestors' had signed. In their Briefs of Evidence, they referred to the sacred marks their ancestors had made from their moko 'tattoo' on those documents, especially Te Tiriti and Te Wakaputanga (the Declaration of Independence) 1835. It is one thing to study such moko designs on paper or in theory, but it is quite another to see the way that they come alive in the voices of our kuia and kaumätua. So while this article began in a small office at the University, it ended on the sea in the Bay of Islands. 
The focus of this article is on identifying instances of the practice of Māori portraying their own moko and those of close relatives on paper. ${ }^{2} \mathrm{On}$ one level these markings acted as legal signatures for land transactions and other formal documents; on another, as I argue here, they can be considered as portraits and self-portraits as they captured the primary identity marker for Māori at the time - their own moko. This paper discusses key examples across time and space, both from specific people (Te Morenga, Hongi Hika, Tuai, Te Peehi Kupe and John Tuhawaiki) and in relation to specific documents (Te Wakaputanga, Te Tiriti o Waitangi and the Wentworth Indenture). It also discusses the regard Māori have for these portraits today.

Moko signatures have typically been examined as part of broader discussions of moko (Simmons 1986, Te Awekotuku 2007), Māori literacy (Haami 2004, Jenkins 1993, King 1978), and specifically $i w i$ 'tribe' literacy (Ballantyne 2011, Jones and Jenkins 2011). Further studies are enmeshed in discussions of specific documents or events (Evison 2006, Hailstone 1993, Henare 2007, Parkinson 2012, Simpson 1990). The only dedicated study is Sarah Gallagher's “"A curious document': ta moko as evidence of preEuropean text culture in New Zealand" (2003: 47) which argued that "moko, like the book, is a physical structure capable of being read by others". Her study identified key examples, such as those by the chief Te Uri o Kanae in the Bay of Islands in 1816 and the sale deed now known as the Wentworth Indenture (1840) in the South Island. Read together these sources provide a survey of key signatories, documents and moments; however, these studies were are done in isolation rather than providing a deeper understanding of the breadth of the practice, both in time and space, as well as an understanding of what this means from a Māori worldview. Here I argue that moko signatures and drawings should be read as "sites of cross-cultural exchange" to use Ballantyne's (2011) term, in the intersection of Pākehā print literacy with Māori oral literacy. As such, the signatures and drawings act as mnemonic devices in that they have the capacity to reveal to contemporary audiences the wider worlds in which our ancestors engaged, not only culturally, but also artistically and politically. Such marks are heralded by Māori as tohu 'signs', not only physical markings on paper, but also as visionary signs of the future, which would become much more complicated than either group, Māori or Pākehā, could have envisaged.

\section{MOKO DEFINED}

Moko is a visible expression of $i w i$, hapu and whannau 'family' identity. It is distinctive from Pacific tatau 'tattoo' in that it was literally carved into the skin in grooves up to a depth of $6 \mathrm{~mm}$. The result was three-dimensional in appearance, with a play of light and dark across the skin. Moko personified 
rank and accomplishment as only high-born people or those with proven abilities were eligible to receive one. As Elizabeth Ellis (1990: 264) notes, "[Moko] was not an isolated art form. It was part of the whole fabric of Maori culture and it changed and developed according to the pressures of the social environment."

Patterns varied according to cultural traditions. Some parts of the moko were generic, while other design elements were unique to the wearer and were often inherited according to whakapapa 'genealogy'. Many men wore moko kanohi 'facial tattoo' over their entire faces, while chosen women received kauae moko on their lips and chins. In addition, there were specific designs on the buttocks, and upper and lower thighs for both men and women, called pakipaki, and rape and pakituri respectively. ${ }^{3}$ Other areas of the body could also receive moko including the back, chest and arms. Each design was named and they were related to each other, resulting in a complex composition which could be "read" by others.

The $t \bar{a}$ moko process would take many hours of work by the tohungatā-moko 'moko practitioner', highly respected members of the community, both men and women, ${ }^{4}$ who worked on commission, moving from one community to the next. Their tool kit consisted of $u h i$ 'chisels' made from albatross bone and other materials: pigments derived from several sources including the awheto caterpillar (Cordiceps robertsii), a handle to haft the uhi onto, and a light wooden mallet to strike the handle. They would also have an oko 'decorated pigment container' and korere, a carved funnel to feed the recipient once the moko was complete. The entire process and all those involved were tapu 'sacred' during the process because of the shedding of blood and involvement of the head, the most sacred part of the body for Māori.

\section{MOKO AS SIGNATURE}

Throughout time Māori have identified themselves vis-á-vis their moko. Its distinctiveness was such that rangatira 'chiefs' began using them in the $1810 \mathrm{~s}$ as symbolic of their selves, as their signature, quite literally. On deeds for the sale of land it was an essential element to have a signature to legally validate a transaction. This practice began in Te Tai Tokerau (Northland), most likely because this was the first location where missionaries wanted to buy land. Later, as literacy became more popular, moko were used as signature in other areas, and increasingly by whole groups of chiefs. Appendix 1 records all known extant examples of moko signatures, from 33 different chiefs, mainly from Te Tai Tokerau (20 named chiefs) and Ngāi Tahu (eight named chiefs).

It is no surprise that the first known moko signature is associated with those who officially brought literacy to Aotearoa. On 24 February 1815 at Rangihoua in the Bay of Islands, the Rev. Samuel Marsden negotiated 
the purchase of more than 200 acres of land at Oihi in return for 12 axes. $^{5}$ The deed was signed by Te Uri o Kanae (or Ahodee a Gunna according to Marsden) and his brother Wharemokaikai of Ngāpuhi. Kaumatua 'elder' Hugh Rihari (Ngāti Torehina ki Mataka) explained the circumstances of this moment (Rihari 2010). Marsden had been keen to purchase land where several Church Missionary Society (CMS) houses were located at Te Hohi (settlers later called it Oihi) while he was still in Sydney. The chief Ruatara advised that this land was owned by Te Uri o Kanae and his brother Wharemokaikai, and so Marsden discussed the matter with them. As Rihari explained:

This was the first 'sale' and had all the hallmarks of an Englishman selling his land to another person. Marsden produced a deed of conveyance drafted by the missionaries, and Te Uri o Kanae's face moko and Wharemokaikai's nose moko were copied onto the paper to validate the deed and demonstrate their agreement. Hone Heke acted as witness and this was noted by putting his thumb print down. ${ }^{6}$

Curiously, but probably reflecting the strata of chiefs there, Hongi Hika drew Te Uri o Kanae's moko, as he was "Confident with a pen" (Jones and Jenkins 2011: 92) after which Te Uri o Kanae made his own mark, which Jones and Jenkins presume was a cross. Wharemokaikai then made his mark from his cheek moko. Unfortunately the original has been lost, leaving only copies by others. ${ }^{7}$

Rihari (2010) doubts whether the chiefs involved realised the significance of the document. As he suggests, "We know that our people were struggling with Western notions of property ownership, and what a 'sale' entailed into the 20th century - so our tupuna surely didn't have a clue about what was happening to their whenua in 1815." Jones and Jenkins (2011: 92) are more critical about this sale, commenting that "Marsden had no legal authority to administer a land deed in New Zealand".

However, settlers and missionaries of the time felt confident that it would indeed stand up in a court of law, for in November 1819 some 13,000 acres of Kerikeri was sold by Hongi Hika to Marsden acting on behalf of the CMS, again in order to establish a second mission station for his new missionaries fresh from England. Hika was keen to seal the deal, which he did with his moko on the deed. Ngāre Raumati chief, Korokoro, was also keen to attract the new settlers and all that this might entail for his own hapu. His brother Tuai had travelled back to the Bay of Islands from Europe with the CMS in July 1819 , and Korokoro hoped that this might give him priority selling rights in relation to where they might want to establish a mission station. This was not to be, however, and Marsden was swayed by Hika, eventually buying a huge tract of land for a mere 48 falling axes (Elder 1932: 153, Sissons, Wi 
Hongi and Hohepa 2001: 26). Given the earlier purchase price this was a dramatic reduction in the value of land, sweetened by the prospect of other benefits that would flow into Hongi's community, such as access to European goods and services.

This land deed (MS-070A, Hocken Library, Dunedin) was signed by both Hongi Hika and his witness, Rewha (or Rewa according to some sources), with part of their moko. Hongi included his tapa-a-a-waha design from around his mouth, the ngu and pōngingia designs on his nose, as well as the tiwhana- $\bar{a}-$ rangi designs on his forehead. It is remarkably similar to the drawing he did of Te Uri o Kanae's moko four years earlier, certainly in terms of the short marks on the haehae lines around the nostrils and the general composition, though it is likely the similarity was because it was a style of moko which was popular in Te Tai Tokerau at this time. Only specific parts of the facial moko were included in this later "signature" but enough so that it was recognisable. Certainly when compared with Hika's carved self-portrait (now in the Macleay Museum, Sydney), completed around the same time, there are differences in designs around the chin between the 1814 carved version and this 1819 deed. This may be attributed to Hongi being more exact with pen and paper than with the chisel, but also that he may have wanted to be more precise on the land deed because of the nature of the document and the desire to be recognised.

Chiefs used their moko, certainly in the north, to signal their consent to other kinds of deals and statements of ownership as well. In 1831, for instance, the ex-British naval captain Thomas McDonnell asked the northern chiefs Te Taonui and Patuone to sign a document registering his vessel, the Sir George Munro, as a New Zealand vessel. McDonnell was intent on establishing a new business in the Hokianga and was reliant on Te Taonui as his patron (Belich 2012). Both Te Taonui and Patuone signed using part of their moko (Binney, Bassett and Olssen 1990: 29). ${ }^{8}$ Long before the Treaty of Waitangi, McDonnell recognised the sovereignty of these chiefs over the country and by asking for their signatures was expecting that others would do the same. This would prove fruitful for him, as he went on to establish a large estate at Horeke on the basis of this document. Unfortunately the physical document has been lost, leaving the oral record alone.

It was during the 1830s that the influx of Pākehā began to have a real impact on Māori, who began holding large inter-hapu hui 'gatherings' to identify strategies of resistance and consolidation in ways that Pākehā would understand. Increasingly this took the form of written documents. Three documents record moko signatures en masse: a letter of petition to King William IV in 1831 and the Treaty of Waitangi and the Wentworth Indenture, the latter both of 1840 (discussed in the next section). 
Letter to King William IV, 5 October 1831 by 13 Northern Chiefs

On 5 October 1831, thirteen Māori chiefs from across Te Tai Tokerau signed a letter to King William IV (now in the National Archives in London) in which they asked for the King's protection from Pākehā seeking to take their lands. All the chiefs signed with parts of their moko to confirm their consent. This is the earliest document of its kind and a forerunner to the 1835 Declaration of Independence and 1840 Treaty of Waitangi. The letter was drafted by William Yate and probably written by Eruera Pare Hongi, a relation of Hongi Hika. The 13 signatories were: Wharerahi and his brother Rewa, Te Haara, Patuone and his brother Tamati Waka Nene, Kekeao, Titore, Tamoranga [Te Morenga], Matangi, Ripe, Atuahaere, Moetara and Taunui [Te Taonui]. The letter was most likely signed at Hika's base at Kororipo Pā, described as "a pa of great mana and tapu where such political, economic, and military issues were often discussed" (Te Aho Claims 2013: 199).

Often rangatira would meet to "discuss and plan political, economic and military matters of regional importance" (Henare 2007: 112). In writing about the petition, Manuka Henare noted that it "marks the beginning of the acceptance of literacy as a new tool of communication, which these leaders willingly grasped for their purposes" (p. 114), or as Tä Apirana Ngata would call it "ngā rākau a te Pākeh $\bar{a}$ " "the tools of the Pākeh $\bar{a}$ '. Henare outlined the process of the signing of this letter in that it would be read out loud to those gathered and then, "those who supported its message would come forward and put their moko mark, a copy of their facial tattoo, to the paper" (2007: 115). Of this signing, he commented (Henare 2007: 115-16):

The moko mark was considered something holy and binding, because it was taken from the skin of the head, believed to be the most sacred part of a leader's body. The tohu, or sign, was the recognised signature of the leader. The placing of the tohu on paper was considered an invitation to a relationship between the leader and his people, and King William and his people. The moral and ethical codes implicit in the act would be underpinned by the cardinal values of reciprocity and obligation. Subsequent generations of descendants of the signatories would refer to such moko marks as 'taonga tapu', a most sacred treasure and commitment.

Henare, Middleton and Puckey (2013: 199-200) observed:

The rangatira signatories signed this letter with their unique and personal moko designs, rather than the conventional sign or mark offered to the illiterate as an alternative to a signature. These moko were 'considered to be something holy and binding', coming from the head, the most sacred part of the body. By signing in this way, the assembled rangatira imbued the document with 
wairua, thereby both communicating their thoughts and representing them and their mana to the asking - their equal.

\section{He Wakaputanga o Te Rangatiratanga o Nü Tireni, October 1835}

Having sent the letter to King George in 1831, the chiefs took further action in 1834 when they chose a flag to represent their new chiefly entity, the United Tribes of Nū Tireni. The flag was named Te Kara, and came to symbolise the 25 chiefly signatories. All but two of those who had signed the 1831 letter also signed another critical document, including my great great-grandfather Te Nana. Te Wakapütanga o Te Rangatiratanga o Nü Tireni was signed in 1835 by a group of 33 rangatira who together became known as Te Whakaminenga o Ngâ Hapū. This group was comprised primarily of chiefs from Te Tai Tokerau, but also by others aligned with them, most notably Te Wherowhero of Tainui who was associated with the Ngāpuhi chief Rewa, as well as Te Hapuku of Ngāti Kahungunu who was aligned with Pōmare of Ngāpuhi. The first signatures were gathered on 28 October 1835 , with the final signatures collected by British Resident James Busby as late as 1839 .

As with the 1831 letter, many of the chiefs signed with their moko and so it became "a chiefly document" (Henare et al. 2013: 210). Others signed with their moko later: Tamati Waka Nene, Huhu, Tona, Kiwikiwi, Taiwhanga and Panakareao. Henare et al. (2013: 213) have written of the effect of Te Wakaputanga as:

...the affirmation by the King's representative (and later the King himself) of the mana or sovereign power of the Chiefs, and the mutual commitment to a relationship under which the chiefs would protect the King's subjects coming to New Zealand and the King would, in turn, protect and assist the Chiefs in fending off any challenges to their mana.

Similarly, Merata Kawharu (2008: 54) has argued that "[s]upport for the Declaration was a way of renewing and broadening the relationship previously established in 1831, 1833 and 1834". Read in this light, the documents were a way of beginning to formalise relationships with various non-Māori groups, such as the French on the one hand, and the British Crown on the other. Rangatira were keen to protect their interests, and saw the power of the European letter and document as one strategy in which to do that. Rangatira had by this time a range of economic ventures which they were keen to foster and enhance, and expected Europeans to maintain order over their own people lest Māori have to sort out matters. 


\section{Te Tiriti o Waitangi /The Treaty of Waitangi, 1840}

Perhaps New Zealand's most famous document, the Treaty of Waitangi, replete with a phenomenal 544 signatures over nine sheets, ${ }^{9}$ was created to be distributed according to tribal region. Hailstone (1993) identified four different types of signatures used by the chiefs on the Treaty: those derived from their moko, simple crosses, quasi-signatures based on Hobson's, and textual signatures. In the first group there are 44 examples from all over the country. This group can be further sub-divided into three groups. The first are those who used single and double spirals, as evidenced from the signatures of Kawiti, Mokoare, Te Rangi Topeora (a Ngāti Toa Rangatira woman), Rehurehu, Te Tutaki, Te Mako, Te Peika, Te Haereroa, Mahuika, Te Potae and Tamaiwakanehua. The next group drew a single spiral as their mark, including Tamaiwhahia and Nuka Taipari from Ngāi Te Rangi. The third group drew a series of parallel lines joined at one end, most likely sourced from the tapa-a-waha lines around the edges of the mouth. Pōmare from the North as well as Te Urimaitai, Te Panepane and Te Tore from the East Coast all marked their identity this way. The last form is interesting as it is a classic mangopare 'shark' design which could have been sourced from anywhere in the face. Te Hakeke of Ngāti Apa signed at Tawhirihoe Pā on 21 August 1840 in this way. Henare et al. (2013: 221) narrowed down the number of chiefs who placed moko signatures on Te Tiriti to 17, and identified them as mostly chiefs from eastern Tai Tokerau, specifically from the hapu of Ngāti Hine, Ngāti Manu, Te Kapotai, Te Uri-o-Te-Hawato, Ngāti Kawa, Ngāre Hauata, Ngāti Hineira and Te Uri Taniwha. This suggests a regional preference for this practice.

Descendants of Pōmare (Ngāti Manu), Kawiti (Ngāti Hine) and Tirarau (Te Parawhau) who attended a hui at Kawiti Marae, Waiomio, in 2011 spoke of how they believed their ancestors' moko represented "sky, water and Papatūānuku" (Henare et al. 2013: 230). They explained that "Tirarau's [signature] is Te Taki-o-Autahi (the Southern Cross), Pōmare's [signature] is Ngā Wai Ata Rere (the meeting/confluence of three rivers), Kawiti's [signature] koru represents Te Whanautanga o Te Ao (the birth of the world)" (Henare et al. 2013: 230). As evidence of the veneration that they gave these marks, the whannau called them "tohu" which can be translated on one level as marks, but on a deeper level as signs which stand in for the ancestors as if they were still here, rather than being just a mark on a paper. And indeed these were tohu, for they foretold of great change for the chiefs and their communities, in unforeseen directions through the process of the Treaty of Waitangi.

Only two chiefs signed all three documents $(1831,1835,1840)$ : the brothers Te Wharerahi and Rewa (Ngāi Tawake, Ngāti Tautahi, Te Patu Keha and Te Uri-o-Ngongo). Both were well-known figures around the Bay of Islands and 
regularly took part in Hongi's taua 'war parties' around the North Island. Rewa was known as a peace-maker, even to this day, and probably because of this inherited Hongi's leadership when he died in 1828 (Sissons et al. 2001: 37). Te Wharerahi, the elder brother, had strong alliances in the Bay of Islands as his wife Tari was the sister of the chiefs Eruera Maihi Patuone and Tamati Waka Nene. Subsequently all three were present when Te Tiriti was discussed in early February. Rewa explained that they did not need any other rulers as they already had their own, while Te Wharerahi argued that the Treaty would bring peace; he was supported in this by his brothers-in-law. The Patu Keha chief Moka was set against it. Ultimately Te Wharerahi signed the Treaty as did a reluctant Rewa, but Moka refused, though his name is there in script.

Eight others signed both the 1835 and 1840 documents: Pōmare II (Ngāti Manu), Kawiti (Ngāti Hine), Pumuka (Ngāti Rangi, Ngāti Pou and Te Roroa), Tama Pukututu (Te Uri o Hawato, Te Uri o Ngongo), Marupo (Ngāti Rahiri, Te Whanau Tara, Te Whanau Rongo, Ngāti Pou, Maturahurahu), another man named Marupo (Te Whanau Rara, Ngāti Hau), Te Awa (Ngāti Paoa) and Te Ngere (Te Uri Kapana, Ngāti Wai, Te Uri Taniwha). These were some of the leading men of the day, and critical advocates for their people in the midst of unprecedented change. They would have known of each other, and most likely showed their solidarity by signing documents together.

The selection of only one part of the moko on these documents is explained by Hailstone (1993: 309) who noted that chiefs were left only a $5 \mathrm{~mm}$ space to sign once their names had been spelt out in European script. Therefore it was just as well that most of the signatories could not write English and instead used, "pictorial figurative marks" to represent themselves. Hailstone (1993: 309) identifies these as, "almost certainly representative of a part of a particular chief's moko". He also points to another custom which appears on the Treaty sheets, which may explain how moko signatures appeared in groups rather than by themselves: in most of the sheets, there is one "style" of signature probably due to chiefs following the style of the signatures already on the sheet. According to Hailstone (1993: 310), "it is likely that whichever chief first signed the respective copy of the Treaty, set the precedent for the others who would not wish to lose face-hence the almost total agreement in terms of style and image used on each sheet".

The Wentworth Indenture, 1840

The same could be said for another important document, which was also grouped tribally. The 1840 Wentworth Indenture (sometimes also called the Wentworth-Jones deed ${ }^{10}$ ) recorded the sale of the entirety of the South and Stewart Islands by eight Ngāi Tahu chiefs to William C. Wentworth and John Jones for $£ 240$ plus annual stipends. ${ }^{11}$ On the second page of the Indenture, 
eight of the most important South Island chiefs signed with their moko. ${ }^{12}$ The Māori names, in parentheses, follow Evison (1990): John Tuhawaiki, Tohowaki, Kaikoreare, Tuckawa (Tukawa), Patuckie (Topi Patuki), Jackey White (also known as Karetai, cousin of Taiaroa), Tyroa (Te Matenga Taiaroa $^{13}$ ), and Bogener (Te Waikai Pokene). These were the leading chiefs of the area at this time, and were seeking to take advantage of keen purchasers of land in Sydney, and thus travelled there to secure a deal.

Three of the signatories (Tuhawaiki, Bogener and Kaikoreare) show their complete moko kanohi 'facial moko', whilst Jackey White's is almost complete except for the left upper cheek spiral (paepae) and related koroaka and putaka (moko elements between the cheek spirals and the ears). Taiaroa and Tohowaki, meanwhile, have only included their forehead patterns, the tapa-a-waha and some of their cheek designs, though whether this was done due to a lack of time, lack of skill or unwillingness to make the complete moko is unclear. It also may be that their actual facial moko were incomplete, though this is unlikely given their inclusion as vendors of such a large tract of land. That these rangatira, or in Ngāi Tahu dialect rakatira 'chiefs', were all signing documents is no surprise, given that, according to Ballantyne (2011: 244-45), "[b]y around 1850, roughly 50 percent of high-ranking Ngāi Tahu men were able to sign their names on land deeds", and this is probably a conservative estimate. Indeed, most of the chiefs also signed their name in text as well, on the third page. The Wentworth Indenture attracted criticism in Sydney because of the inequities of scale, with some 20 million acres being sold for what seemed to be a pittance. Indeed, the Queen's representative, Sir George Gipps, stepped in and subsequently nullified the deal through the courts in Sydney.

\section{Multiple Signings: The Case of John Tuhawaiki ${ }^{14}$}

There is only one case of multiple moko signatures by the same person, those drawn by Kati Ruahikihiki chief John Tuhawaiki. He drew/signed his moko at least six times between 1838 and his death in $1844,{ }^{15}$ including on the Wentworth Indenture in 1840, and on a range of documents now in the Hocken Library in Dunedin, ${ }^{16}$ including on a letter dated 28 March 1843 declaring ownership of Ruapuke Island (Tuhawaiki 1840).

Each of the signatures is slightly different and because of that we get some sense of the idiosyncrasies of his moko. In particular, the titi 'forehead'is formed from two large downwards koru facing one another, whilst it is clear that there was no paepae (upper spiral on his left cheek). There are also differences in all three self-portraits along the putaringa edges by the ears and along the upper forehead. In the third drawing, his inclusion of eyes and lips reveals a new awareness by Tuhawaiki of the representation of the 
individual, with the result bearing a close relationship to Western modes of portraiture. This is a distinct shift from his incomplete signature on the Wentworth Indenture where his eyes are mere dots.

Tuhawaiki also stands out in this history of Māori self-portraiture as he was able to write his name in script which he included on two of his selfportraits. This reveals him becoming more accomplished and confident in using literacy; some of the signatures are simple text, whilst others are characterised by a flourishing at the ends to his letters. They also allow us to date the self-portraits, as they usually accompanied the drawings. For instance, textual signatures from 1840 (including his signature on the Treaty of Waitangi on 10 June 1840) are relatively simplistic without any joined letters, compared with the drawing in the Hocken Library, which is very finely executed. ${ }^{17}$ In those which he signed both with his moko and with text, it is highly likely that Tuhawaiki was making a political or social statement about who he was; he was stating very firmly that he was a chief and owner of the land and distinct from those to whom he was selling. He was proud of his identity as Māori, specifically Kati Ruahikihiki. As Ngahuia Te Awekotuku (2007: 29) so eloquently summarises:

Tuhawaiki's image did not fade from the face of the earth; instead this precisely composed and authoritative self-portrait endures as one of the most compelling symbols of that extraordinary time. Much more than a Ngai Tahu war leader and clever entrepreneur, Tuhawaiki reaches across time as a gifted artist and powerful visionary, whose words and face continue to inspire.

\section{Signs of a Rangatira: Te Rauparaha}

With the influx of new settlers from England and their eagerness to purchase land, more deeds began to be signed with the moko of their owners. This was not just limited to the North however. In 1833 in the lower North Island, Ngāti Toa Rangatira chief Te Rauparaha used his moko as a signature on a document presented by Captain John Blenkinsopp of the whaler Caroline, which the chief believed was for "the right to procure wood and water... in exchange for a ship's cannon" (Burns 1983: 184). Blenkinsopp had married Te Rauparaha's first cousin (and the daughter of Te Peehi Kupe), probably as a political alliance, which would have meant that he was "well received" ( $p$. 184) when he introduced this deal. However, Te Rauparaha later discovered that it was not a contract for provisions, but rather a land sale. Burns described his reaction: "Infuriated, he tore the paper up, shouting that the contract was ended. The cannon proved to have been spiked, and was useless" (p. 186).

This might not be the only time that Te Rauparaha signed deeds in this way. In 1839 a man identified as "Te Ropera" signed a land transfer with William Barnard Rhodes for 256,000 acres at Waikanae in exchange for $£ 150$ 
in the form of arms, ammunition, tobacco and various items. The provenance to Te Rauparaha is from the identification of the vendor as "Te Ropera" by Webb's Auction House which sold the deed in 2012. ${ }^{18}$ Rhodes had come from Sydney to purchase land in and around Wellington "to establish cattle runs and trading stations" (Patterson 2012). Ultimately Rhodes signed deeds for some 2 million acres in both the North and South islands, much of which was disallowed by the Land Claims Commission. That same year (1839) Te Rauparaha was approached by Colonel William Wakefield who was keen to buy land as well, and a deed was settled in payment for guns, blankets and other goods. The deal was subsequently disputed and eventually nullified by Lieutenant Governor William Hobson in 1840. Te Rauparaha was adamant he had to protect his lands, and would sign the Treaty of Waitangi twice in expectation that this would guarantee protection.

On the 1833 deed, Te Rauparaha has carefully shown his facial moko as well as small naturalistic eyes and a mouth, adding a further dimension to the work. In reality he had less moko than he shows here, a fact corroborated by many portraits of him over his lifetime, particularly the intricate 1847 drawing by William Bainbridge (ATL, QMS-0122-140A), but this may have had more to do with a limited time frame than any deliberate act of omission on his part. In the 1839 deed, Te Rauparaha has placed his moko on a 90 degree angle to the text. Equally unusual, he has only included part of his moko with no nose designs and only the tiwhana-a-rangi on the forehead, the tapa-a-waha around the mouth and the korowaha spirals around the jaw. In fact, someone else has added to the moko on the deed, perhaps to "even out" the design, though it is too obvious to seriously be considered part of the original design. Because of Te Rauparaha's status and mana it is unlikely that any Māori would do such a thing, particularly as the moko is from his head, the most tapu part of his body.

\section{WRITTEN EVIDENCE OF MOKO SIGNATURES}

It seems that the drawing of moko remained a fairly rare occurrence in the early 19th century, enough to invite comment from several early Pākehā. Dumont D'Urville witnessed Māori signing in this way in the early 1820s and recognised it as such:"While they were drawing up the deed of purchase in writing, the leading chiefs had a special moko (design) put on their faces. Then they added this same moko at the bottom of the deed, as a sort of signature" (in Rosenman 1987: 193). This is indeed an unusual account, as it appears that the rangatira received their moko just before signing the document, and it was this fresh design that was added to the deed. It is interesting that D'Urville only saw it as "a sort of signature" [my emphasis] even though it would have been treated as legally sealing the deal. 
Pākehā considered this way of signing a curious practice, yet one which would be regarded as binding should any suggestion of impropriety arise. Shortland (1974: 84) gives some insight into this when he wrote in 1843-44:

There [in Sydney] land speculations were then in fashion, and their formal appearance, with the addition of a tattooed face, scrawled in place of a signature, gave them a marketable value [my emphasis]. In many cases, goods to a large amount were sent to New Zealand without any security that they would ever be paid for, other than the deposit of such a document as the one above.

Private collector Dr Thomas Hocken, at an unknown date, annotated (in pencil) an 1839 grant of land to James Fowler from Karetai of iwi Kati Ruahikihiki which included his moko (Karetai1839). Hocken (n.d.) wrote: "Specimens of tatu [sic] signatures where the natives unable to write, signed deeds by drawing their tatu [sic] marks. The method was adopted long before the days of colonization when traders, chiefly from Sydney, purchased land." Certainly during the early years of the 19th century, trade between the Bay of Islands and Sydney in particular was brisk, with much travelling back and forth of both Australian traders keen to exploit local resources and Māori keen to learn more about the wider world, in particular the purchase of muskets.

The 1840s saw an increased use of moko signatures. Jameson (1842: 234) noted that the practice was de rigueur: "...every individual having a right in the land... was necessary, not only to satisfy the demand of the chief, but also of those adherents and relatives of both sexes [my emphasis], and to have with their signatures or attested marks (moko) affixed to the deed of sale." Certainly we see more Māori using moko as their mark on a wide range of documents at this time. By the mid-1840s Māori culture had begun to feel the impact of colonial contact and many $i w i$ and hapu were focused on stopping any further European expansion onto their lands. Under the auspices of the Treaty of Waitangi of 1840, Governor Grey had started to flex his legislative muscle and slowly but surely impose English law upon the land and its people. As a result, Māori began to realise that their signatures on the Treaty could have implications much greater than they could have anticipated at the time. Moreover, by the end of the 1840s more Māori were literate and able to sign using text and were keen to follow how Pākehā signed documents. Further, the Government was becoming increasingly wary of land dealing done on the sly, and so were watchful of new land sales. This undoubtedly influenced Pākehā in the type of signature that they would accept on such papers. The result was that moko signatures were not seen on any land deeds after the mid-1840s.

In addition to the moko placed by chiefs on letters and other formal documents, there is a second corpus of drawings also by Māori but on informal papers such as journals and letters. Only eight examples have been found to 
date, but undoubtedly with further research more will be uncovered. Appendix 2 lists extant examples, beginning in 1815 with a drawing by Te Morenga on board the Active and finishing in the 1880s with Tãwhiao.

\section{Te Morenga's Self-portrait, 1815}

The earliest occurrence of Māori drawing their own portraits was in March 1815 by Te Morenga, the Ngāti Hine rangatira from Taiamai in Northland. He had met Rev. Samuel Marsden and European traveller John Liddiard Nicholas when they had landed in the Bay of Islands. He would soon become Marsden's closest Māori friend, travelling with him around New Zealand and to Sydney, acting as his interpreter and ally. At this time Te Morenga was one of the most powerful figures in the Bay of Islands, along with Hongi Hika and Pōmare.

On 9 March 1815, on board the missionary vessel the Active, Nicholas gave Te Morenga a pen, "which I directed him to use for the purpose [of drawing his own moko], and which he now handled for the first time" (Fig.

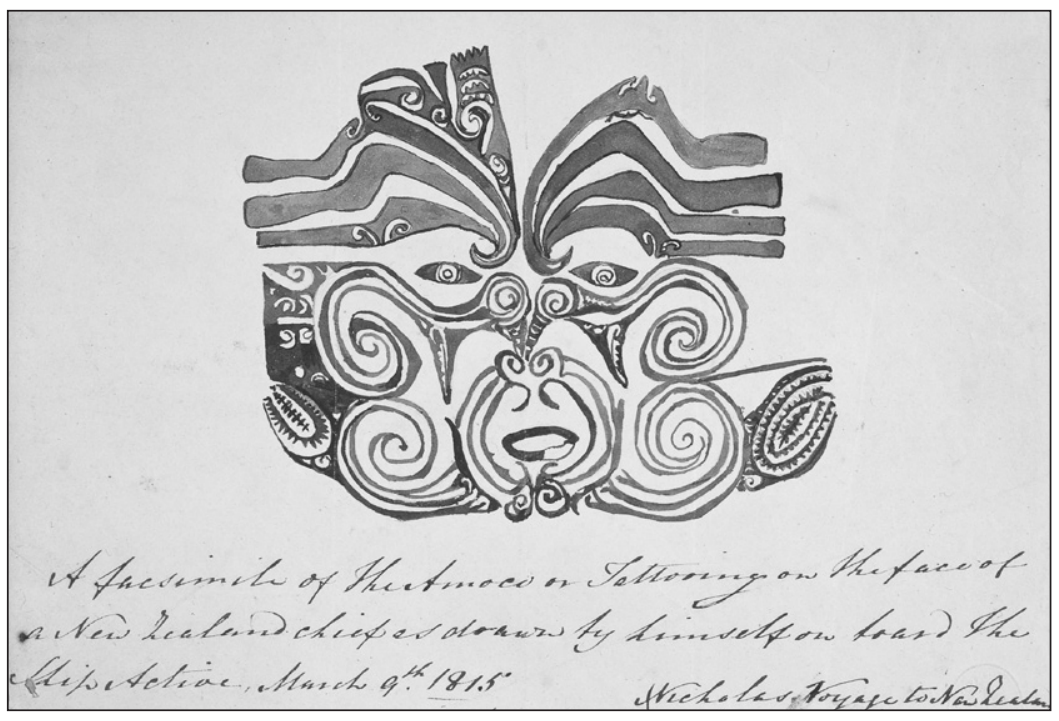

Figure 1. A facsimile (from Nicholas 1817 [II]) of Te Morenga's moko, as drawn by the chief in 1815 while aboard the Active (see text for details). Courtesy and copyright: Alexander Turnbull Library, Wellington, collection reference A080-061. 
1). ${ }^{19}$ The validity of the original was later questioned by Enid Ellis (1978), who claimed that the original was actually redrawn by Samuel Neele, the engraver who worked on Nicholas's publication.

Te Morenga's self-portrait is one of the most distinct in this second group in that it is obviously asymmetrical (reflecting the way in which moko for men were asymmetrical), omitting as it does specific parts of the design, such as the titi moko at the top of the forehead, and the koroaka or cheek spiral on the sides by the ears. The drawing is all the more remarkable given the fact that this is the first time that Te Morenga had picked up a pen, according to Nicholas at any rate. Also worth highlighting is the detail which has been included, and the way in which Te Morenga was able to render complex double spirals with relative ease and precision.

\section{Tuai's Two Portraits of his Brother Korokoro, 1817-19}

There is only one instance of a person drawing the face of someone else twice. Buried in the Special Collections of the University of Birmingham (UK), and most recently unearthed by Alison Jones and Kuni Jenkins, is a remarkable drawing by Tuai (sometimes also called Tui) of his brother Korokoro, both of Ngāre Raumati from the Bay of Islands. In 1818 Tuai had become famous along with Titere, both ex-students of Samuel Marsden's school in Parramatta, Sydney, for their travels to England in 1818, some of the first Māori to journey there (Te Aho Claims Alliance Report 2013: 194).

As with Te Peehi's drawing mentioned next, Tuai's drawing is exceptional in that it records the moko of his older brother Korokoro. Jones and Jenkins (2011: 152, 156) suggested that this may show “...a spiritual visit from Tuai's elder brother, with whom he had a close relationship, and under whose authority he was travelling". As they noted: "So intensely could Tuai recall the details of his brother's face that he traced it, in detail, with pen and ink; this face was for Tuai rich with tribal meaning and brotherly comfort" (p. 156).

Even more significant is that there is a second portrait, also made in England, by Tuai of his brother Korokoro (Fig. 2). In comparing the two, both portraits have eyes included (very rare in general) and have the same moko designs across the face, and through to the forehead. The Birmingham example is much more detailed, however, with each of the heavy lines around the mouth and across the forehead showing the haehae cuts. There is also more information about the upper forehead, and the designs on the right cheek appear more balanced. The Auckland example, by comparison, may be an earlier rendition, given the simplicity of some of the design fields, and the filling in of the 'tiwhana' lines on the forehead. Despite this, the drawings provide an incredible insight into Tuai's memory and the intricacy of the moko of the period. It is even more poignant given the fact that shortly after 


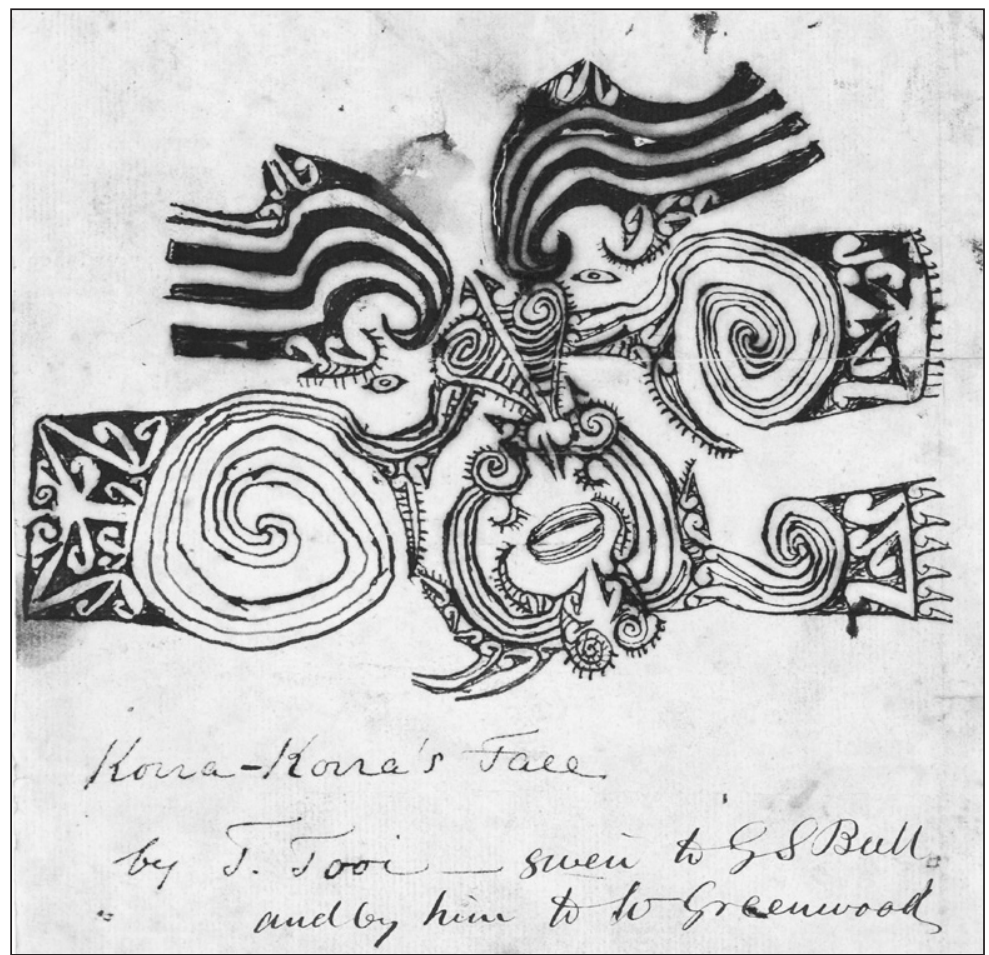

Figure 2. Drawing by Tuai (Ngāre Raumati) of his brother Korokoro, done in England, in 1818. Courtesy and copyright: Auckland Libraries, Sir George Grey Special Collections, GNZMMS 147.

Tuai's death in 1826 his Ngāre Raumati people based around Te Rāwhiti were besieged by Ngāpuhi and enslaved by them. The survivors were distributed throughout the Bay of Islands thus bringing an end, some say, to Ngāre Raumati as a major political force in the area.

Te Peehi Kupe's Self-Portrait, 1824-25

Being in England was also the impetus for another moko drawing. In 1824 the Ngāti Toa Rangatira chief Te Peehi Kupe boarded the ship the Urania and then refused to leave until he was taken to England for an audience with King William IV (which he was successful in gaining). He was also keen to secure firearms for use by his people, not surprising given recent military events 
that had seen the deaths of many, including two of Te Peehi's young sons. He arrived in England and spent at least a year there, ${ }^{20}$ including eight months in Liverpool. During this time he made a number of drawings. ${ }^{21}$ One of these was undertaken while he was having his portrait done by John Sylvester (now in the Rex Nan Kivell Collection, National Library of Australia, NK1277 T1372). During the sitting, Te Peehi became most interested in how he was being rendered, and was adamant that his moko be replicated accurately; accordingly we may presume that the portrait is correct. As Craik (1830: 330-31) described it:

The figure, he [Te Peehi] explained, not being by any means a mere work of fancy, but formed according to certain rules of art, which determined the direction of every line. It constituted, in fact, the distinctive mark of the individual; and one part, indeed, of that on his own face, the mark just over the upper part of his nose, Tupai constantly called his name; saying, 'Europee man write with pen his name, - Tupai's name is here," pointing to his forehead.

Te Peehi's knowledge of moko and his insistence on the precision of his moko led him to begin drawing his own moko for Sylvester. Craik (1830: 331-33) explained:

Still further to illustrate his meaning, he would delineate on paper, with a pen or pencil, the corresponding marks in the amocos $[$ moko] of his brother and his son, and point out the difference between these and his own. But it was not only the portion of the decoration which he called his name with which Tupai was familiar; every line, both on his face and on the other parts of his body, was permanently registered in his memory.... The depth and profusion of the tattooing, he stated, indicated the dignity of the individual; and according to his rule, he must himself have been a chief of distinguished rank, as scarcely any of the original skin of his countenance remained.

Te Peehi signalled that moko in general was an indicator of rank and mana, and because of the "depth and profusion" of his own, it was a clear signal of his own status within Māori culture. Te Peehi's memory of moko was so extensive that he was also able to draw from memory the moko kanohi 'facial moko' of his younger brother Te Rangihiroa and eldest son Te Hiko o Te Rangi, a well-known carver and waka 'canoe' builder, as well as a chief and the man he had entrusted their people to whilst he was in England. As an English contemporary of the day observed (Craik 1830: 332-33):

When Tupai's [Te Peehi's] talent in this species of drawing was discovered, many applications were made to him by his Liverpool acquaintances for specimens of his art; and for a fortnight a great part of his time was occupied in 
manufacturing these pictures of the scars with which his face was impressed.... Some of his performances also exhibited representations of the figures on other parts of his body; and he drew for Dr. Traill [his physician] the amocos [moko] of his brother and of his eldest son.... On finishing the latter, he held it up, gazed at it with a murmur of affectionate delight, kissed it many times, and, as he presented it, burst into tears.

It is interesting how Craik sees Te Peehi's moko as "scars"- -he had earlier called them "stains" - and in many ways they were; moko recorded Te Peehi's biography, so that he could point out his whakapapa and his position in the $i w i$ and hapu for his foes and allies alike. In England, moko were altogether unfamiliar and novel, and Te Peehi's marked him out as someone from the wider Pacific region. Te Peehi was keen to fit in with British high culture, and was "constantly on the watch to observe the behaviour around him" (Craik 1930: 322). Te Peehi's popularity was inextricably tied to his facial moko, as can be evidenced by the requests from "his Liverpool acquaintances" for a memento of his visit and their relationship. At the end of the day though, Te Peehi was in unfamiliar waters, and by inscribing the faces of his brother and son he was able to retain and reinforce his connection with them through their moko.

When King Tāwhiao subsequently visited England in 1884, seeking redress for land grievances, the Russell Square, London-based artist H. C. Seppings Wright took the opportunity to make his portrait. Tāwhiao, as with Te Peehi, also insisted that his moko designs were depicted in a high quality manner. On the second day of the sitting, Tāwhiao drew a number of works to illustrate this. As one contemporary commentator noted (Anon 1884: 2):

But the King was able to explain that these designs were reproductions of tattooing art with which he is familiar. More than that; by means of signs and the aid of a lady's photography which was lying on the table, he showed clearly that one of his designs was a fac-simile of the decoration on the chin of his Royal spouse.

Just as with Renata Kawepo (see below), drawing the moko of a close female relation/spouse seems to have been of much interest; for Seppings Wright we might assume that this was an artist-to-artist interest, if he indeed considered the drawings to be art. For Tāwhiao, it was essential his moko be accurately depicted, as people, certainly Māori, would identify him because of this alone. In addition, making errors in depicting the design might lead to breaches of tapu; certainly, as Roger Blackley pointed out in his article humourously entitled "King Tawhiao's Big O/E", Tawhiao was already feeling vulnerable to breaches of personal protocol during this visit (Blackley 2012: 37). It is unfortunate that neither the portrait, nor Tawhiao's drawings have been found to date. 
Renata Kawepo, 1843

Two remarkable drawings by Renata Kawepo of Ngāti Kahungunu in the journal of missionary William Cotton in 1843 provide much information not only about the people they depict, but also because of the moko names that are inscribed on the drawings. The first drawing depicts the flattened out moko kanohi of a male chief and identifies the separate parts of the designs. On top of the pencil drawing another moko has been added, this time of a woman, complete with not only her moko kauae but also with hotiki 'design between the eyebrows', the latter a form usually reserved for high-born women. However, the male moko depicted is not that of Kawepo, if we compare it to a photograph of him as an older man in the 1880s (he died in 1888).

Kawepo has a fascinating, but not uncommon, biography. When he was a young man he was taken as a prisoner-of-war by Ngāpuhi in the 1820s and was kept by them for ten years before being released. Over this decade he was given a moko because of his status, most likely by a travelling tohunga-tāmoko, as Ngāpuhi had none on hand. He spent time in the Bay of Islands in the late 1830s, and in 1843 he accompanied Bishop Selwyn on a three-month visit to various Anglican mission stations around the country. William Cotton meanwhile was a young Anglican missionary recently arrived from England, but semi-fluent in Māori despite this, the ship's journey having been a long one and with Māori on board.

The drawings are all the more remarkable because Kawepo was not known as an artist, and both are detailed and complex, suggesting he had spent some time on each of them. Actually composing these designs, especially the men's one, required time and patience, particularly given that it is so clear and well-proportioned. As with Te Rangikāheke's profile drawing of the face (see below), it was important to render the moko just right, not only because it was a moko, but also because each part of the design was being named.

\section{Other Drawn Self-Portraits}

In the Alexander Turnbull Library (ATL) in Wellington are four further examples of moko self-portraits. The earliest is one captioned "Moko or face pattern drawn by a native from memory" c. 1843 (ATL, 891791/2). In this pencil drawing, there is a very strong sense of the artist, by the way in which the moko is rendered on a slant looking down to his left. It is disconcerting, in that it appears as if the person is about to come right out of the paper. The moko is shown almost complete, with clear asymmetry, particularly along the koroaha and putaka designs by the ears.

About the same time, the artist George French Angas copied a drawing originally made on a slate by a man called Tawhito (ATL F.1081551/2; Neich 1993: 162, Fig. 78). As Angas only travelled around the North Island between 
Auckland and Wellington over a period of five months, thus we can assume that the drawing was done in this region. Angas drew many portraits of Māori at the time and so became fairly confident in portraying moko.

There are two distinct features about this drawing. Firstly it is rendered in side profile, a manner of representation that was not altogether unknown in Māori art, as for instance, manaia figures on carvings are always shown in profile. In this case, however, the side profile was in relation to a human figure. Secondly, the artist has shown himself with eyes, a full head of hair and dressed in a kākahu 'cloak'. Neich (1993: 162-63) called this "a conceptual mix [in which] the individual is still denoted by his tattoo, but his naturalistic appearance is also accorded some recognition". In this way the artist did not want to only show himself as having moko, but as a person with hair and clothing in a method used by Pākehā artists of the period. This may have been affected by the context in which the drawing was produced, as at this time writing slates had been provided to some Maori communities as part of the push for literacy and often were offered first to chiefs to engender their support. The resulting self-portrait effectively translates traditional carving practices, which not only rendered an individual's moko but also their physiognomic details, into a two-dimensional format.

In another self-portrait from 1844 the artist focused on the separate parts of the moko and their individual names; this may have been done by a person named Te Whatanui (ATL, C-103-001-1). The drawing was included in the scrapbook of Walter B.D. Mantell who in 1844 was in South Taranaki and Porirua, before he moved to the South Island in 1848. The tribal affiliation of this man could be any one of a number of $i w i$, many of whom were on the move during this period. In this drawing, the artist has named specific parts of the moko, including te ngu 'upper nose' and te wha 'chin'. The face has been only partially rendered by lines representing the left hand side of the nose, the tapa-a-waha (rays from the nose to the chin) and the putaka spiral (lower spiral on the left cheek). The reason for the partiality of the moko is unknown; perhaps Mantell only wanted part of the design, or perhaps the artist was only keen to relinquish part of his moko.

The fourth drawing in the Alexander Turnbull Library has a humorous origin. In the late 1840 s, the young Thomas Collinson spent time around the West Coast of the North Island and sketched a series of landscapes. He also met the Te Ati Haunui-a-Paparangi chief Kawana Pitiroi Paipai at Putiki Pā in Wanganui. Collinson attempted to draw Paipai in 1846 along with his whare (home) (ATL, A-292-032). Collinson noted on his drawing: "The tattooing I drew did not satisfy him so he drew himself." Paipai's self-portrait shows ovals for the eyes and mouth, tapa-a-a-waha lines around the mouth, two koru for the chin, and the outer edges of the tiwhana rays on the forehead. Below this, as if to confirm the artist/author, Kawana has signed his name in text "+Kawana Pitiroi Paipai". 
Te Rangikaheke's Drawing of Moko, Especially the Face, Pre-1858

One final example to be added to this corpus was drawn by Wiremu Te Rangikāheke of Ngāti Rangiwewehi, whose 800-page manuscript (1854) was used as the basis for much of the work published by Sir George Grey (Manuscript No. 89, now in Auckland Libraries). Within these books are a number of drawings of moko, not only from the face (MS. pp. 450-51) but also designs of the pühoro 'thighs', raperape 'buttocks' and tuarā 'back' (MS. p. 452). The primary intention was to illustrate the text and in doing so record for future generations this knowledge. Arini Loader (2008: 68) argued that the material written down by Te Rangikāheke is not actually his, but rather belongs to his Te Arawa people, and that "they are communally held stories that bind Arawa people through time and space and speak to an Arawa worldview in an Arawa nation in which the sovereignty of Te Arawa is assumed". In this way, it can be argued that each of the moko depicted here are specific to Te Arawa, particularly as Te Arawa were one of the last $i w i$ to enjoy moko practitioners expert in the $u$ hi technique. Whether these drawings are self-portraits or not is difficult to ascertain due to a lack of comparable visual material. We can assume, however, given the detail of the drawings that the moko were either his own, or those of close relatives.

\section{THE ART OF MĀORI PORTRAITURE AND SELF-PORTRAITURE}

It is crucial for these self-portraits and portraits to be understood within Māori worldviews, rather than trying to make them fit into existing Western European paradigms. I have elsewhere written about the nature of both portraiture and self-portraiture in relation to those renderings by Māori of their moko (Ellis, in press) but for the purposes of this essay three major considerations are outlined. Firstly, within the Western European forms, there are a spectrum of types of depictions, from the idealised through to the photorealist. In this way, what we see in the paintings and sculptures is frequently not exactly accurate. Rather, what we see is what the artist wanted us to see. Secondly, these forms have changed over time and space, particularly with the advent of photography. Lastly, it is important to remember that the genres of portraiture and self-portraiture are not the sole prerogative of artists based in Western Europe but, as argued here and elsewhere (Caro 2010, Pearlstone and Ryan 2006), were occurring in communities across the globe and through time. As Caro (2010: 165) argued: "The production of the Native subject outside the dominant signifying system is not only possible; it has always occurred." In addition, this article follows Caro's (2010: 165) intentions to "disrupt the stability of Western notions of Native identity, [and] also to recognize that indigenous views of identity are themselves, plural, and, at times, irreconcilable". 
Within Māori art specific ancestors were depicted in carvings and given moko to emphasise their significance in the whakapapa. Neich (1993: 142) wrote of the practice of Māori portraiture, identifying it as being distinct from the Western European tradition as it was not based on a "visual likeness". However, it is argued here that Māori did aim for visual likeness, in that the self-portraits were recognised not only by other rangatira, but also that some chiefs were fastidious about the accuracy of their moko when portrayed by Pākehā artists and were aiming for an exact likeness.

These were individuals who wished to assert their personal mana, as well as that of their $h a p \bar{u}$, and by extension their $i w i$. These men were distinct personalities, however, evidenced by the fact that their individual names have come down through the whakapapa along with their exploits. Their mana extended out to their personal belongings which were arguably their own to create and dispose of, if only for the benefit of their people. Witness, for instance, the ways in which waka taua and other carved objects were distributed through various social and political networks in order to uphold the mana of the chief, as well as their people. In this way, individualisation of ownership did indeed occur; if there were any concerns then ultimately the chief would be the recipient of a visit from a taua muru 'plundering party' in order to rectify this and return social order.

Neich (1993: 142) continued that in relation to portraiture, certainly within Māori carving, it was "metonymical, in that a characteristic part of the individual was used to signify the whole person". This applies to the moko signatures in that with so many of them, what is depicted is the essence of the face as represented with a single distinct part of the design which the chief felt would symbolise him. What is probably the most unique aspect of 19th century Mãori self-portraiture is that the physiognomic features were omitted in preference to the lines of the moko. Many of the moko signatures/ self-portraits are of a complete full face moko. Of these, about half include physiognomic features, particularly the eyes, nose and lips; in others parts of the self-portrait seem to have been deliberately omitted. In such a case it may be that the signatory did not want all their moko to be portrayed, keeping some of it for themselves, and placing just enough of the design so as to be recognisable by other chiefs.

The portraits, the second group, are distinctive from those on documents as most of them have included physiognomic details, albeit the most obviousthe eyes and the mouth. In this way there is a double portrait in operation. On one level there is the moko, which is flattened out and thus takes into account both profile and frontal design elements. On the next level, there are simple physical details of the mouth and lips taken front on which are generic and probably bear little if any relationship to the actual physiognomy of the 
artists. The inclusion of hair and cloak in Tawhito's portrait, for instance, adds further depth, both spatial and contextual, to the image.

Another unusual feature of the moko signatures/portraits is that the artists/ signatories flattened out their moko. Thus their drawings were rectangular in shape, with a central line down the centre of the face, dividing the composition. This mode of representation is complex and requires skill and precision. In the drawings, the moko is always depicted as well-balanced, in which the lines and spirals are clearly rendered and achieve a sense of unity and harmony. Being able to achieve this was no simple matter, and reflected how the chiefs thought of their mana, and themselves.

The drawn self-portraits reveal a degree of idealisation by the chiefs. The way in which they perceived themselves comes through clearly. The moko which they drew not only showed their external selves, but also revealed the way they felt about themselves. In some cases, the men depicted themselves with more moko than they had in real life, perhaps to give themselves more status. This is not uncommon with self-portraits in that the artist wishes to present the best possible face for posterity.

\section{Significance of the Signatures/Drawings}

A statement has been made that different patterns constituted heraldic devices which distinguished different tribes. That this is an assumption based on an English background is proved by the fact that chiefs invited tattooing artists from other tribes who had acquired a reputation for their particular designs. The visiting artist reproduced the design of a particular school, and if it was a tribal device, the patient would have been branded with the distinguishing pattern of the artist's tribe, which is absurd. (Hiroa 1949: 299)

The drawn self-portraits discussed above reflect, more than anything else, encounters and relationships between Māori and Pākehā, both here and overseas. In England, Te Peehi Kupe was deep in foreign soil and probably used the opportunity to draw such figures to reacquaint himself with key members of his whänau and to keep that relationship warm. The same could be said for Tuai's picture of his brother, and Tâwhiao's drawings of his wife and himself. These types of drawings were encouraged by the English people they were staying with, and embraced by the artists who were keen to capitalise on being new faces in the local community.

In New Zealand these moments of engagement seem to have been on a similar level, with Pākehā being interested in the most obvious visual difference between themselves and Māori- that of moko. On one level Māori enjoyed the attention, but ultimately when they thought that Pākehā scribes might misrepresent their moko, they picked up the pen themselves and created a new practice, such as the case with Tâwhiao and Te Peehi Kupe. 
In doing so the chiefs affected the pieces of paper on which they wrote on a totally different level. Brad Haami (2004: 24) recognised the relationship between tapu and these forms of documents:

To have the korero [words] and oral traditions recorded on paper in books, letters and diaries gave these documents a degree of sacredness. A special relationship governed by notions of separation, restriction and prohibition was created between the writer, the person written about, and the guardian of the document. The marks, moko images and signatures of chiefs written on paper were deemed tapu. To damage these documents was to insult the signatories.

Michael King (1978: 14) had earlier noted that: “... records may have intensive degrees of tapu because they contain much of the tapu and mauri that belonged to the topic and the person who recorded it". Hailstone (1993: 307) also mentions this:

For the Maori people the prints represent much more than simple marks, they are part of their ancestors and as such maintain their spiritual qualities quite often moving them to tears or private reflection, quite unrelated to the Treaty's political or legal relevance. For the European, they are seen as art objects which fit European art-making traditions. In either case, cultural consciousness regarding the Treaty is increased regardless of the reference point.

This would certainly explain the presence of the moko signatures on important documents, particularly the petition to King William and on the Treaty of Waitangi. In many ways, the marks which these rangatira put down could be seen as setting aside the documents as important and warranting special behaviour around them. Māori used to set aside specific geographic areas with pou rähui, wooden markers daubed with red kokowai pigment. This would be done for any number of reasons, including to prevent over-fishing, to identify burial grounds, or to signal the site as belonging to a specific chief. I argue that in this way the rangatira signatories were continuing this traditional practice.

The fact that the moko or the signature, even when partially rendered, was recognisable by others was commented on by Polack (1840 [II]: 43):

The men chiefly delight in these stains $[$ moko] and incisions which are so far from being confined to one fashion or pattern, that tribes are known by such distinctive marks, and many chiefs whose countenances have never been seen by a distant tribe, are known, simply by the distinguishing mark which has been peculiarly engraved on their countenances. We had several opportunities of testing this fact, from having taken some likenesses of the chiefs residing in the north, and on showing them to some families resident 
at a distance upwards of 400 miles, they were immediately distinguished and named, though no connection existed between those persons, or had even at any period seen each other.

The Wentworth signatures together provide the most complete picture that we have of any tribal group's moko at any point in the 19th century, though whether this signals a tribal style or the style of a particular tohunga-tā-moko is unclear. The fact that the moko were drawn by the wearers themselves makes them particularly important, and offers contemporary Ngāi Tahu moko practitioners a glimpse into their moko heritage.

These signatures and drawings were not just any drawings, they were the artists themselves, and tantamount to their person. A self-portrait of a rangatira was seen as the rangatira, rather than simply a representation of him. Rangatira were particularly concerned that their moko be replicated accurately when their portraits were being done by Pākehā artists. This comes through clearly as the catalyst for Paipai, Te Peehi and Tāwhiao drawing their own moko. Given that the Pākehā artists would not have had any training in the intricacy of moko design and aesthetic, and given that these chiefs would have received such education as part of their tuition as chiefs, it is not surprising that the rangatira were able to depict their moko so clearly. Their mana was at stake. They wanted to be recognised by their moko more than anything else, and as such they needed to oversee its depiction very carefully.

That those who drew their self-portraits were usually chiefs and always men is not a coincidence. Chiefs were the ones to whom missionaries, traders and travellers were dependent upon in terms of their safety and well-being as well as their future. If considered favourably by the chiefs then they were able to purchase land or organise other such dealings. Moreover, chiefs were conscious of the impact of these drawings, in that their full-face moko provided virtual photographs of them that could be used by the journal owners as aide memoire of their travels in New Zealand, and also to keep the relationship between them warm.

It is a pity that we have, so far, no record of a Māori woman drawing her own moko, but this reflects gender stereotypes at the time more than anything else. It was to Māori men that Pākehā spoke and entered into cordial relations with; Māori women were seen and treated by Pākehā as they themselves treated their own women, that is, as chattels of their male relations, such as their fathers, husbands, brothers and sons. In reality of course Māori women were not considered this way within Māori culture; they were chiefs in their own right in some areas, most notably in the tribal regions of Ngāti Porou and Ngāti Toa Rangatira. They held land and they fought alongside men in battle. Perhaps further research will reveal some instances of this practice. 
Ultimately what these chiefs did was a brave move, in that they were risking their own personal tapu by extending out from their persons onto paper. To this day their drawings remain central to their descendants and are revered in much the same way as photos and paintings and other images. Indeed, these drawings are all the more special as they were made done with their ancestors' own hand.

These signatures and drawings chart a shift in Māori culture not to replace the oral with a written culture, but rather to extend existing patterns of oral and visual language to include paper. From the 1840s onwards, Māori used text in their carvings to identify key ancestors and in response to growing literacy among their people. In the whare whakairo 'decorated meeting house' named Te Hau ki Turanga (opened in 1845), the chief Raharuhi Rukupo of Ngāti Kaipoho of Rongowhakaata chose to add text to his carved figures. No doubt this was to demonstrate his literacy, as well as to confirm his status within Māori art history as an innovative artist. The fully decorated meeting house itself was a new concept with its proliferation of carvings on the interior of the house. In a similar way, weavers began incorporating their own names in the borders of cloaks and other spaces. These signatory chiefs then, often also artists in their own right, shifted back and forth between modes of representation of the self, whether that be in text, or through moko.

The drawings are put forward here as a form of indigenous self-portraiture. It is unclear whether this was a cultural practice within traditional Māori arts, as the only references we have come from carvings from the early 19th century. It represents a shift of personal space in that chiefs began to see themselves in the third person, a state necessary for creating self-portraits. In many ways they had to be objective where they could in order to make as true a likeness of themselves as possible. On the other hand, they also wanted to show their own status as chiefs, and they needed to maintain a distance between themselves and the people. As such their moko had to emphasise this distance, and did so by depicting their moko as unique and more ornate than anyone else's, and thus were recognised by others as this chief or that.

Ultimately, these chiefs have left us a significant corpus of tohu, in which we can chart varieties in moko designs across the country, and in doing so we have a snapshot of what moko practice was in specific moments in time, most notably in the 1830-1840 period (with the King William letter, Declaration of Independence, Wentworth Indenture and Treaty of Waitangi). That so many instances have been uncovered demonstrates that this practice was in fact more widespread than previously thought, and they have become embedded in several iwi's print traditions, most notably Ngāpuhi's and Ngāi Tahu's. It is here that chiefs made their signatures as political statements of their rangatiratanga or 'sovereignty', whether that was to sign away their land or 
to call on a King to save it. These signatures need to be read not as standing in for the chief, but rather as being the chief. The fact that they were made in pencil or pen rather than in oil paint or photography is immaterial. Their moko endure through time, binding future generations to the work of their ancestors and reminding them that they must continue their fight.

$$
* * *
$$

Self-portraits and portraits of moko have a relatively short history (1815-1884) within Māori art history, yet they provide many revelations about my people and how they saw themselves. They represent not only visual records of the people who made them, but on a deeper level were made as strong political statements about the mana of the men who drew them. Moko were particularly important in this respect as Māori actively sought to assess how Pākehā would fit into their world. Māori were keen to assert their independence and sovereignty. The sale and purchase of land affected not only Māori ways of life, but also, more importantly, how they saw themselves. For people so connected in terms of their identity with their türangawaewae 'homeland', its alienation caused waves of loss, still being felt today in many areas.

These moko are revered as portraits of the men who drew them by their descendants today. In some ways they are more sacred to them, for the simple fact that they were produced by the hand of their ancestor who chose his best side to be shown. Here then we have the transfer of moko from the skin onto paper, undertaken by chiefs, many of whom were not familiar with print and paper. These marks continue to resonate with the tapu of their producers and inspire ihi 'power', wehi 'awe' and wana 'fierce energy' in those who meet them today. For us from Te Rawhiti, the moko of our chiefs remains integral to our identity, especially as we move through our Waitangi claims. They are a window into our past, and provide inspiration that we may continue the legacy of those chiefs and their brave moves in pen.

\section{ACKNOWLEDGEMENTS}

I would like to especially thank Manuka Henare, Mark Kopua, Roger Neich, Damian Skinner and Ngahuia Te Awekotuku for their most useful feedback and advice on this essay over the years. I would also like to thank Susie Davies of the Macleay Museum, Sydney for showing me Hongi Hika's self-portrait in their collection. Thanks to the anonymous referees for their comments. For kind use of their images, I thank Auckland Libraries, Alexander Turnbull Library, and National Archives, Wellington. An abridged version of this essay is in press in Repositioning Pacific Arts. Artists, Histories, Objects, edited by Anne Allen. The original research was compiled as part of a Royal Marsden funded project entitled "Tā Moko: Culture, Body Modification 
and the Psychology of Identity" (\#01-UOW-002). Parts of this essay have been presented at the Pacific Arts Association Conference, Christchurch (2003), The Tatau/ Tattoo: Embodied Art and Cultural Exchange, c1760-2000 Symposium in Wellington (2002), as part of the Art History Departmental Seminar Series at the University of Auckland (2004) and as a lecture for a graduate Art History paper (2005). My thanks to the Faculty of Arts, University of Auckland, for funding a Summer Scholarship (2012-13) to research the literature relating to moko signatures.

\section{ABBREVIATIONS}

AIM Auckland War Memorial Museum Library, Auckland

AL Auckland Libraries, Auckland

ATL Alexander Turnbull Library, Wellington

GNZMMS Grey's New Zealand Māori Manuscripts, Auckland Library, Auckland

NA National Archives, Wellington

\section{NOTES}

1. Adapted from the well-known whakatauki 'proverb' composed by Ta Apirana Ngata. It loosely translates as 'your hands grasping the tools of the Pākehā'.

2. It is possible that there were earlier instances; however, due to a lack of comparative material, both visual and oral, it is difficult to establish any earlier examples.

3. I have chosen to use the terms of Tohunga-tā-moko 'moko specialist' Tame Poata (Tom Porter) as published in Te Awekotuku, Mau Moko, pp. 230-33. The originals are in Michael King's papers related to his book with Marti Friedlander, MokoMaori Tattooing in the 20th Century, in the Alexander Turnbull Library (Papers MS-Group-0667). Poata was from Ngāti Porou, my other tribe, and one of the few whose practice incorporated both $u h i$ and needle work around the early 20th century. In the case of missing terms, I have used those with kind permission from Tohunga-tā-moko Mark Kopua, also from Ngāti Porou.

4. There are few mentions of women moko practitioners, but they did exist. D'Urville mentioned seeing a female prisoner-of-war in the Bay of Islands in the early 1830s completing a moko on the entire back of the wife of a chief. Michael King also mentions two women working in the early 20th century (Kuhukuhu Tamati and Te Hikapuhi Poihipi Clayton Te Kiri). In the 21st century women like Henriata Nicholas and Christine Harvey are continuing the art of moko.

5. At least one of these axes has survived and is held in a private whānau collection.

6. Brief of Evidence B 013(a), WAI 1040, 2010), 10-11.

7. There may have been earlier examples, as Alison Jones and Kuni Jenkins (2011: 35) write of Māori signing on as sailors on European whaling ships in the Bay of Islands from 1800 onwards. As they describe, "Maori men were required to sign with a cross, like the other sailors who could not write their names - a statement that they were legally bound over to work on a particular vessel for a certain period." 
8. This was in reaction to the boat's seizure in Port Jackson and confiscation of its cargo.

9. Two originals plus a further five copies were made for distribution. See Michael King's (2009) fascinating documentary series Lost in Translation for a personal insight into the moments surrounding the signing of many of the sheets.

10. There are two versions of this deed; Wentworth's version is the Mitchell Library in Sydney.

11. The sale did not go ahead as it was stopped by the Government of the day.

12. The last of the eight chiefs, Patuckie, departed from the others in that he drew his face in a naturalistic style reminiscent of Western art. He also did not include any moko. Perhaps he did not have any.

13. Tyroa quite possibly used his moko as signature following the practice of his father Korako and cousin/brother-in-law Jackey White (Karetai). He may have brokered this deal, as he had earlier sold a parcel of land to John Jones in 1838 when in Sydney; his daughter would later marry another of the men from the 1838 deal, Edward Weller, probably as a strategic alliance. John Jones owned seven whaling stations in and around Foveaux Strait, and this 1838 deal was considered to be very cheap for the price (Facto 1945: 7).

14. There are several cases of chiefs signing more than once. Te Haara (Ngāpuhi) signed the King William petition in 1831 with lines of moko and is also recorded in Polack (1840 [II]: 49) with a signature of spirals and parallel lines. Kawiti (Ngāti Hine) also has his moko reproduced by Polack (1840 [II]: 50) though unfortunately this was redrawn and stylised by Polack; Kawiti also signed the Treaty of Waitangi on 13 May 1840 with an unfurling double spiral. Titore (Ngaitawake) also signed twice, once on the King William letter and later on a document reproduced by Polack again (p. 49).

15. At the end of writing this MS., I discovered three of these six manuscripts in the collection of the Hocken Library, frustrating but one of the challenges of research materials becoming available over time. These will hopefully form the basis for a further project.

16. These can be found by doing a search on the Hocken Library archive database called Hakena using the keywords "Tuhawaiki Moko".

17. There are two published images of this self-portrait (Robley 1987: 13, Fig. 8).

18. This document is now in private hands.

19. The original was later acquired by the collector Ken Webster in London and in 1970 was acquired by the Alexander Turnbull Library, Wellington.

20. Te Peehi became ill with measles and was unable to return home, staying on in England. Whilst there, he was given many gifts which he sold in Sydney on the way home. He bought hundreds of guns and shipped them home which gave Ngāti Toa Rangatira a distinct military advantage in the years to come. Te Peehi was killed in Kaiapoi Pā in 1828.

21. Craik's 1830 book contains the only remaining image we have by Te Peehi, and unfortunately this has been redrawn by the book's engraver. Most people, however, credit the drawing to a similar one redrawn from this copy in 1963 by Gordon Walters. 


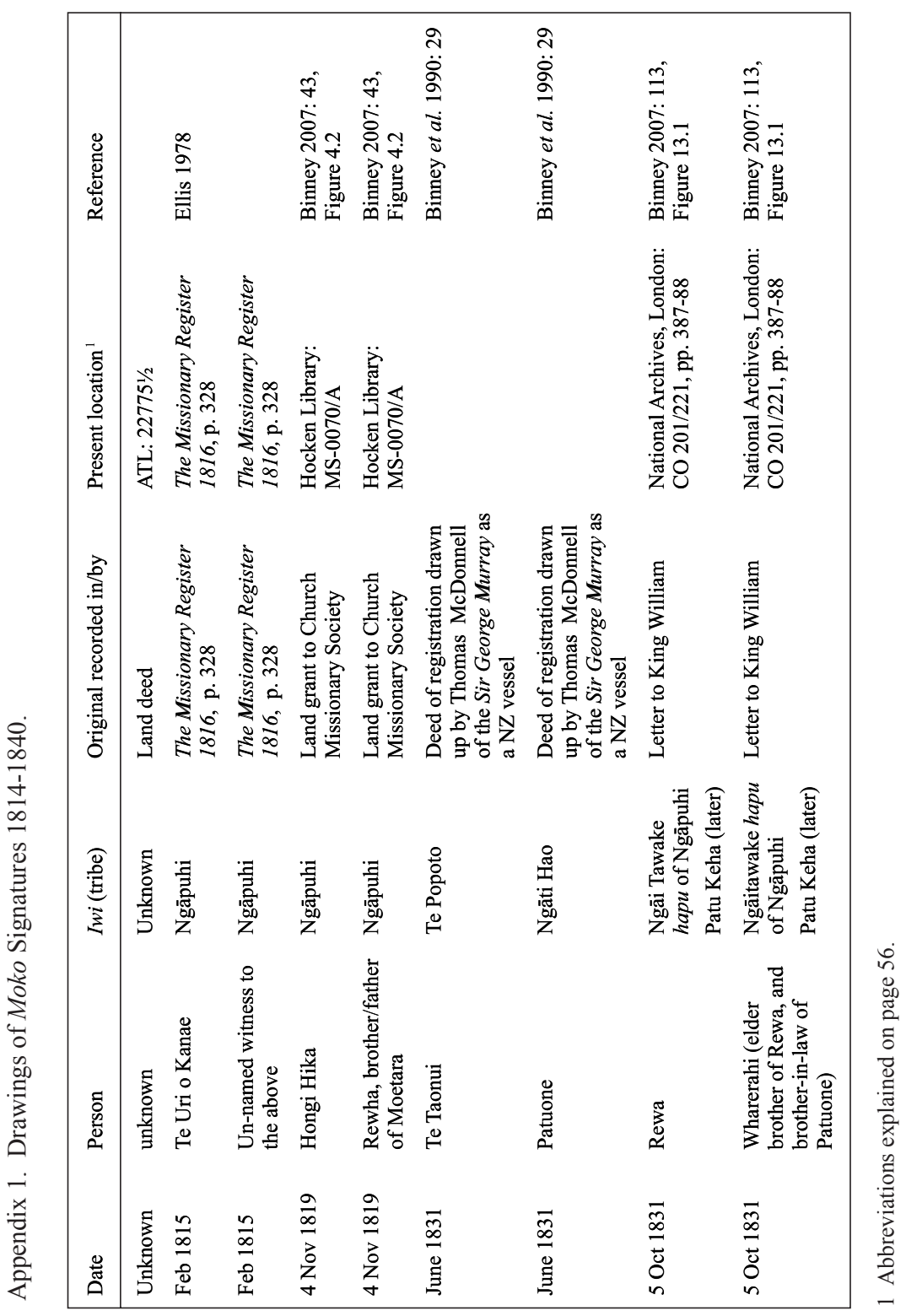




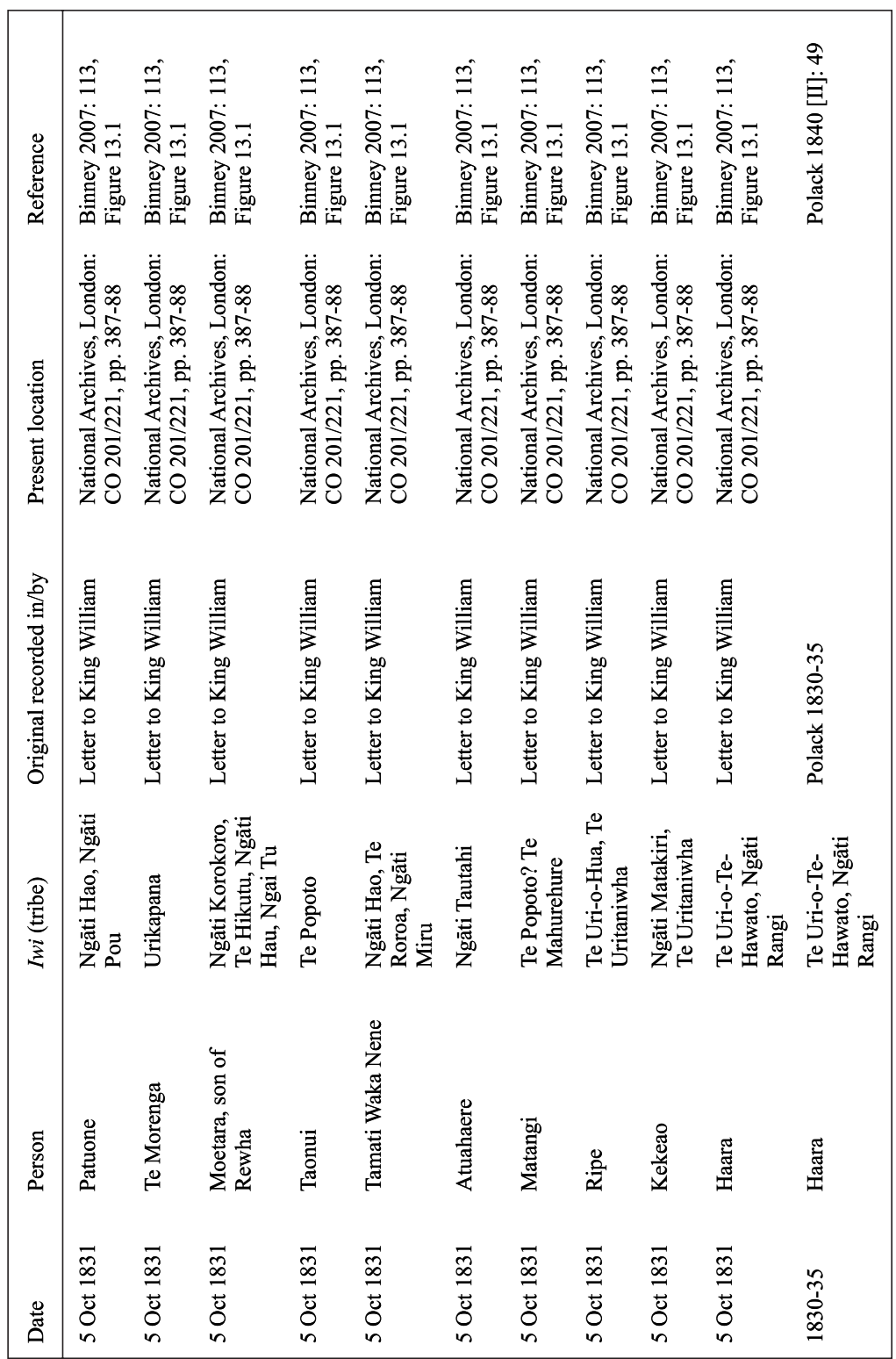




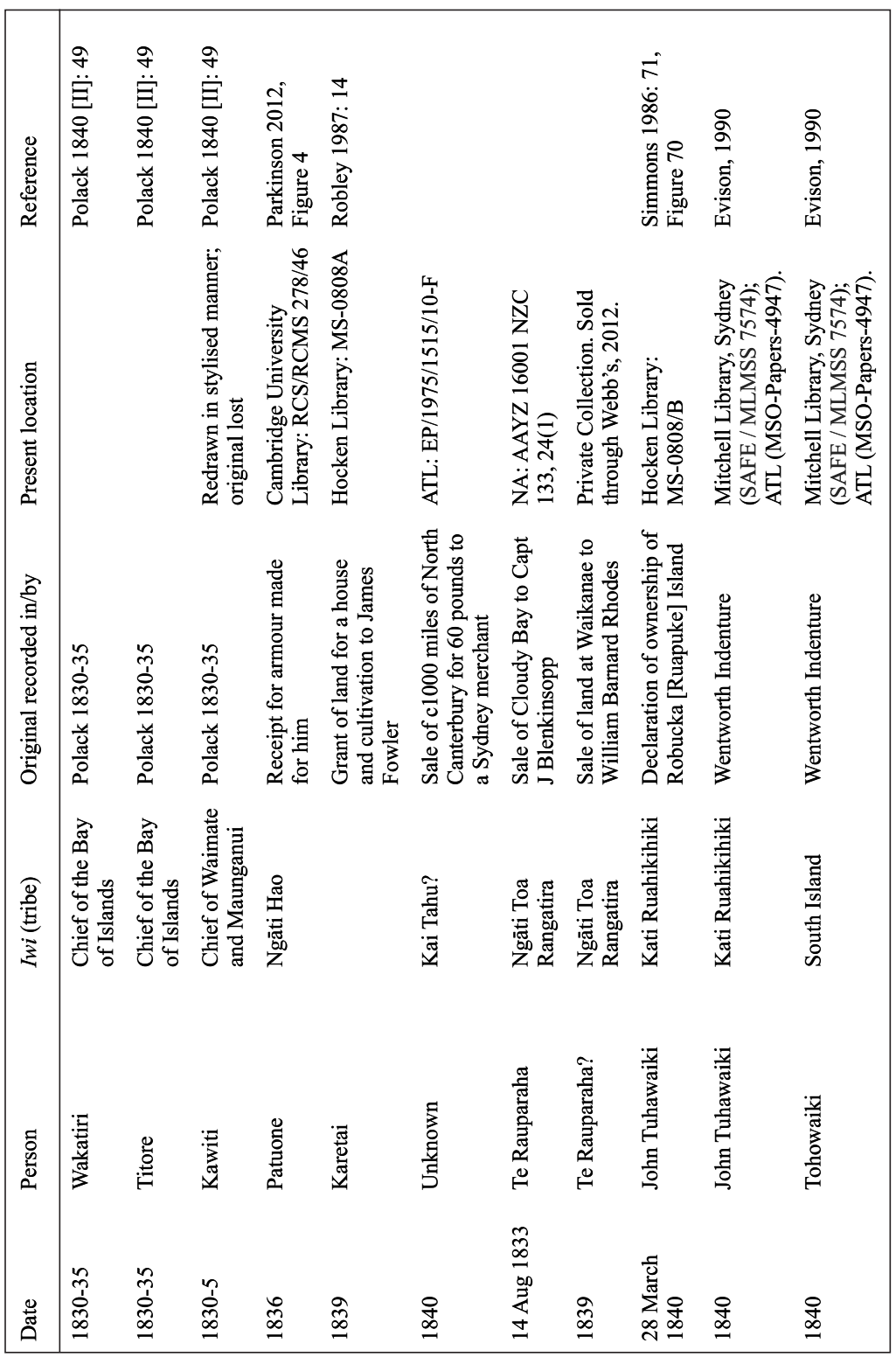




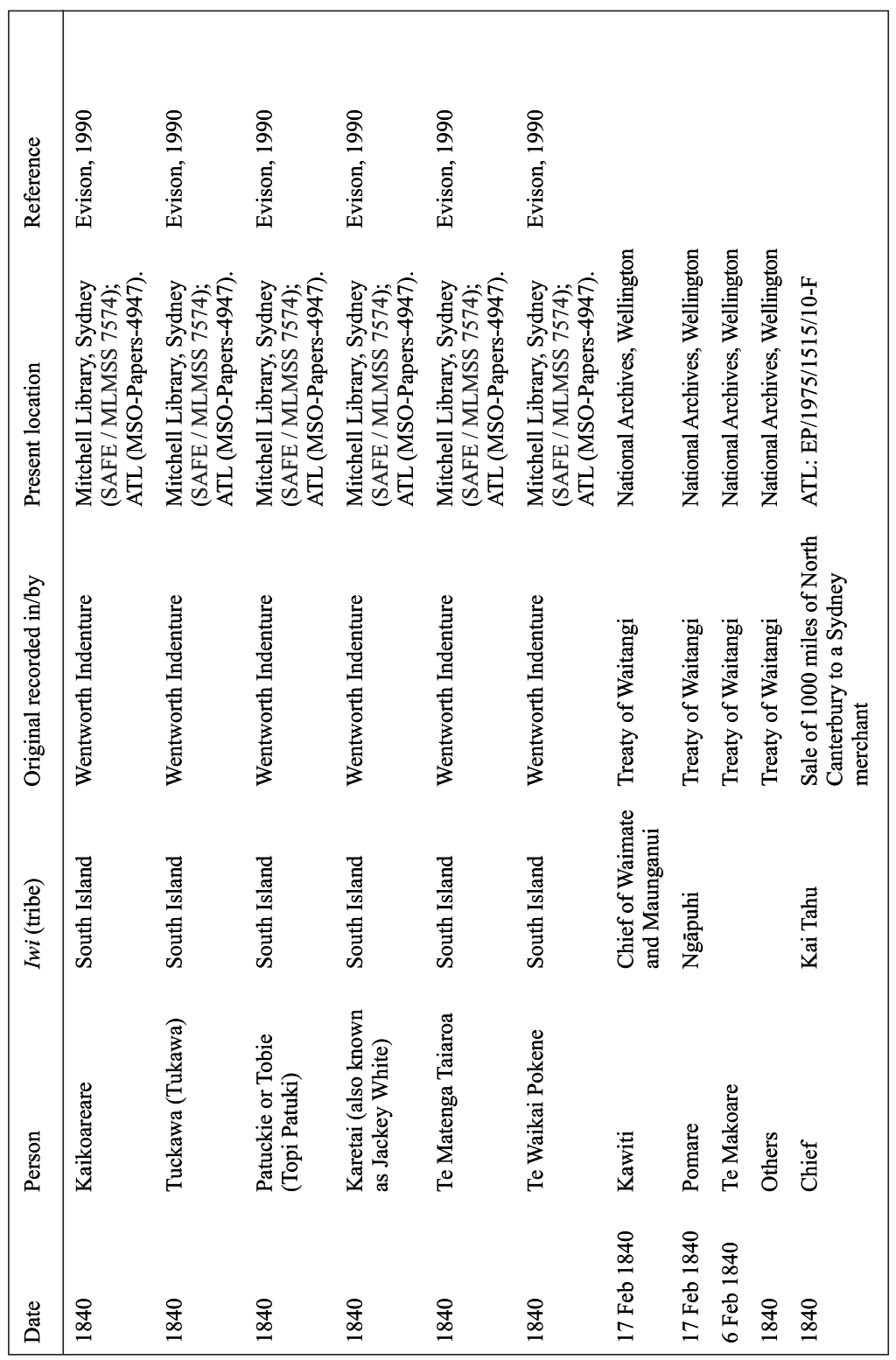




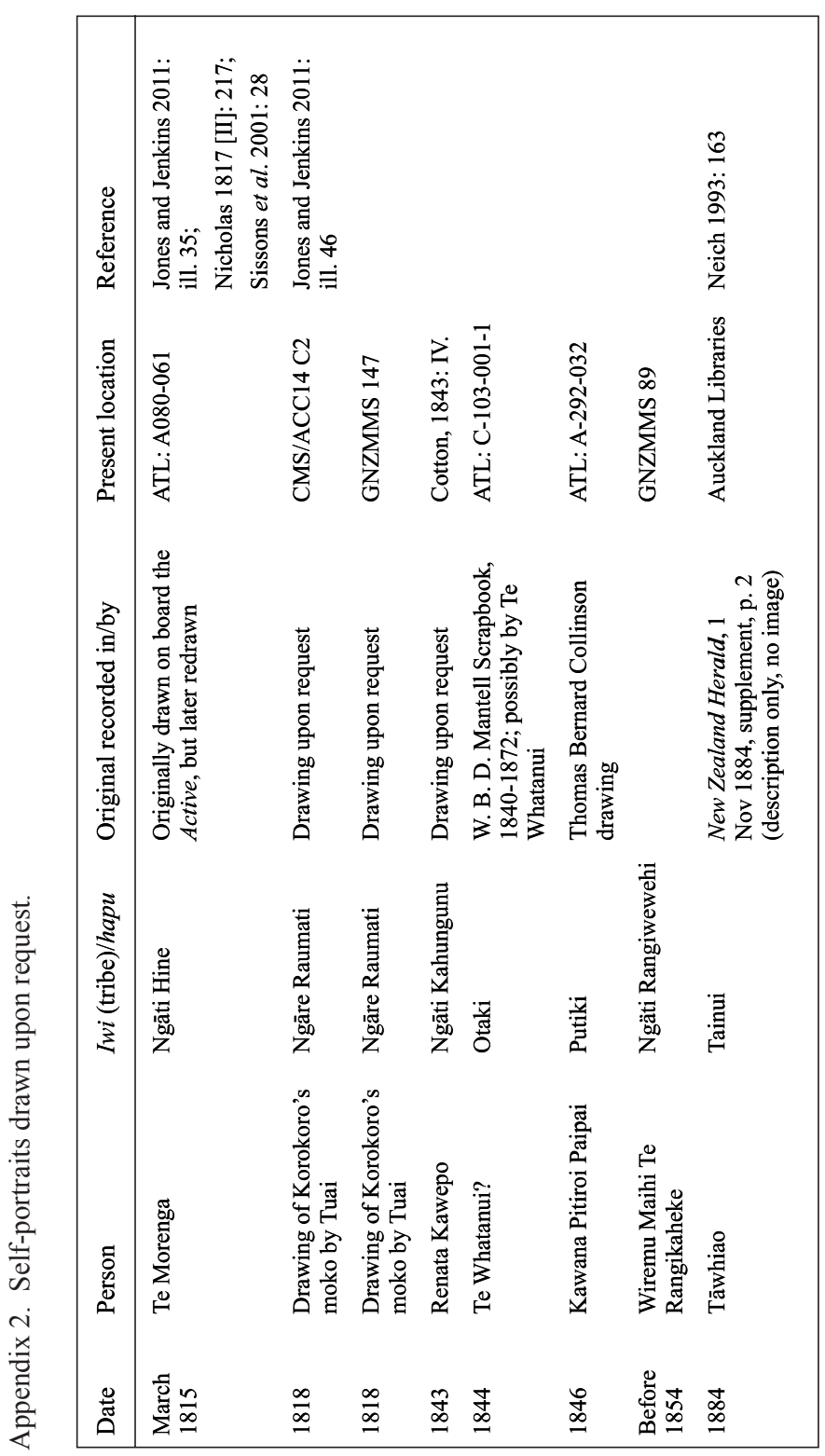




\section{REFERENCES}

Anon., 1884. Painting Tawhiao's portrait. New Zealand Herald XXI (7164), Nov 1884 , p. 2.

Ballantyne, Tony, 2011. Paper, pen, and print: The transformation of the Kai Tahu knowledge order. Comparative Studies in Society and History 53 (2): 232-60.

Belich, James, 2012. McDonnell, Thomas. Dictionary of New Zealand Biography. Te Ara - the Encyclopedia of New Zealand. Updated 30-Oct-2012. Available at: http://www.teara.govt.nz/en/biographies/1m33/mcdonnell-thomas

Binney, Judith (ed.), 2007. Te Kerikeri 1770-1850. Auckland: Auckland University Press, pp. 112-18.

Binney, Judith, Judith Bassett and Erik Olssen, 1990. An Illustrated History of New Zealand. Wellington: Allen and Unwin.

Blackley, Roger, 2012. King Tawhiao's big O.E. Turnbull Library Record 44: 36-52. Burns, Patricia, 1983. Te Rauparaha-A New Perspective. Auckland: Penguin.

Caro, Mario A., 2010. The Native as Image. Art History, Nationalism, and Decolonizing Aesthetics. Unpublished dissertation, University of Amsterdam.

Cotton, William C., 1842-43. Journal. Canberra: State Library of New South Wales.

Craik, George L., 1830. The New Zealanders. London: Charles Knight.

Elder, John R. (ed.), 1932. The Letters and Journals of Samuel Marsden 1765-1838. Dunedin: Coulls Somerville Wilkie Ltd. and A. H. Reed.

Ellis, Elizabeth, 1990. Moko: An Exhibition of 19th Century Portrait Photographs of Maori with Tattoo: From the Photograph Collection of the Alexander Turnbull Library. Wellington: Alexander Turnbull Library.

Ellis, Enid M., 1978. Early Prints of New Zealand, 1642-1875. Christchurch: Avon Fine Prints.

Ellis, N.G., 2000. Only skin deep? A Maori perspective on the appropriation of moko. Paper presented at the 1999 Conference of the Art Association of Australia and New Zealand, Victoria University of Wellington. Published in Pre/dictions: The Role of Art at the End of the Millennium. Department of Art History, Victoria University of Wellington, pp. 49-52.

- in press. Maori self-portraiture. In A. Allen (ed.), Repositioning Pacific Art: Artists, Objects, Histories. Hindmarsh, South Australia: Crawford House.

Evison, Harry C., 1990. Karetai. Dictionary of New Zealand Biography. Te Ara-The Encyclopedia of New Zealand, updated 30-Oct-2012. URL: http://www.teara. govt.nz/en/biographies/1k1/karetai. Accessed 18 July 2014.

Evison, Harry, 2006. The Ngai Tahu Deeds: A Window on New Zealand History. Christchurch: Canterbury University Press.

Facto, E.P., 1945. The kingdom of "Bloody Jack". Sydney Morning Herald 24 November, p. 7.

Gallagher, Sarah K. J., 2003. "A curious document": Ta moko as evidence of preEuropean text culture in New Zealand. Bulletin (Bibliographic Society of Australia and New Zealand) 27 (3-4): 39-47.

Haami, Bradford, 2004. Putea Whakairo: Maori and the Written Word. Wellington: Huia Publishers. 
Hailstone, Max, 1993. Te Tiriti (The Treaty). Visible Language 27: 302-19.

Henare, Manuka, 2007. The Māori leaders’ assembly, Kororipo Pa, 1831. In J. Binney (ed.), Te Kerikeri 1770-1850. Auckland: Auckland University Press, pp. 112-18. Henare, Manuka, Angela Middleton and Adrienne Puckey, 2013. He Rangi Mauroa Ao Te Pō: Melodies Eternally New. Auckland: The Mira Szászy Research Centre, Business School, University of Auckland.

Hiroa, Te Rangi [Sir Peter Buck], 1949. The Coming of the Maori. Wellington: Maori Purposes Fund Board.

Hocken, Thomas, n.d. Penciled annotations added by Hocken to MS-0808/A (Grant of land by Karetai to James Fowler, for a house and cultivation). Manuscript MS-0808/A, Hocken Library, University of Otago, Dunedin.

Jameson, R. G., 1842. New Zealand, South Australia and New South Wales. A Record of Recent Travels in the Colony. London: Smith, Elder and Co.

Jenkins, Kuni, 1993. Becoming Literate-Becoming English. Monograph No. 14. Auckland: Research Unit for Maori Education, University of Auckland.

Jones, Alison and Kuni Jenkins, 2011. He Korero. Words Between Us. First MaoriPakeha Conversations on Paper. Wellington: Huia Publishers.

Karetai, 1839. "Grant of land by Golantine to James Fowler", signed by Karetai of Kati Ruahikihiki with his moko. Manuscript MS-0808/A, Hocken Library, University of Otago, Dunedin.

Kawharu, Merata, 2008. Te Tiriti and Its Northern Contexts. Wai 1040, \#A20. Wellington: CFRT.

King, Michael, 1978. Some Maori attitudes to documents. In M. King (ed.), Tihe Mauri Ora: Aspects of Maoritanga. Auckland: Methuen, pp. 9-18.

King, Michael, 2009. Lost in Translation. Documentary directed by Nevak Ilolahia and John Keir, Auckland: Ponsonby Productions.

King, Michael and Marti Friedlander, 1992. Moko: Māori Tattooing in the 20th Century. Auckland: David Bateman. (2nd edition)

Loader, Arini, 2008. Haere mai me tuhituhi he pukapuka: Muri iho ka whawhai ai tatou: Reading Te Rangikaheke. Unpublished MA thesis, Victoria University of Wellington.

Missionary Register 1816. Auckland: Auckland Institute and Museum.

Neich, Roger, 1993. Painted Histories. Auckland: Auckland University Press

Nicholas, John Liddiard, 1817. Narrative of a Voyage to New Zealand, Performed in the Years 1814 and 1815, in Company with the Rev. Samuel Marsden, Principal Chaplain of New South Wales. 2 volumes. London: Printed for James Black and Son.

Parkinson, Philip G., 2012. Tuku: Gifts for a king and the panoplies of Titore and Patuone. Tuhinga 23: 53-68.

Patterson, Brad, 2012. Rhodes, William Barnard. Dictionary of New Zealand Biography. Te Ara - the Encyclopedia of New Zealand. Updated 30-Oct-2012. Available at: http://www.teara.govt.nz/en/biographies/1r7/rhodes-williambarnard

Pearlstone, Zena and Allan J. Ryan (eds), 2006. About Face: Self-Portraits by Native American, First Nations, and Inuit Artists. Santa Fe, New Mexico: Wheelwright Museum of the American Indian. 
Polack, Joel Samuel, 1840. Manners and Customs of the New Zealanders. London: J. Madden.

Rihari, Hugh, 2010. Brief of Evidence for the WAI 1040 Waitangi Tribunal Hearing. Reference: B 013(a).

Robley, Horatio, 1987. Moko; or Maori Tattooing. Papakura: Southern Reprints.

Rosenman, Helen (trans.), 1987. An Account in Two Volumes of Two Voyages to the South Seas by Captain ... Jules S-C Dumont D'Urville ... to Australia, New Zealand, Oceania 1826-1829 in the Corvette Astrolabe and to the Straits of Magellan, Chile, Oceania, South East Asia, Australia, Antarctica, New Zealand and Torres Strait 1837-1840 in the Corvettes Astrolabe and Zélée. Melbourne: Melbourne University Press.

Shortland, Edward, 1974. The Southern Districts. Christchurch: Capper Press.

Simmons, David, 1986. The Art of Maori Tattoo. Auckland: Reed.

Simpson, Miria, 1990. Nga Tohu. Wellington: National Library of New Zealand.

Sissons, Jeffrey, Wiremu Wi Hongi and Pat Hohepa, 2001. Ngā Pūriri o Taiamai : A Political History of Nga Puhi in the Inland Bay of Islands. Auckland: Reed, in association with the Polynesian Society.

Te Aho Claims Alliance Report 21 February 2013. Auckland: The Mira Szászy Research Centre, Business School, University of Auckland.

Te Awekotuku, Ngahuia, 2007. Mau Moko. The World of Māori Tattoo. Auckland: Penguin.

Te Rangikaheke, Wiremu, 1854. "Maori manuscripts: Description of the ceremonies observed on the occasion of tattooing a chief and the method of performing the operation.” MS-GMSS89, Grey Māori Manuscript Collections, Sir George Grey’s Special Collections, Auckland Libraries, Auckland.

Tuhawaiki, John, 1840. Declaration of Ownership of RobucNeischa [Ruapuke] Island, 28 March, 1840. Manuscript MS-0808/B, Hocken Library, University of Otago, Dunedin.

Wentworth Indenture, 1840. Deed of sale between William Wentworth and John Jones and Ngāi Tahu chiefs Tuhawaiki, Tohowaki, Kaikoreare, Tukawa, Topi Patuki, Karetai, Te Matenga, and Te Whaikai Pokene. SAFE/MLMSS 4947, Mitchell Library, Sydney; MSO-Papers-4947, Alexander Turnbull Library, Wellington.

\section{ABSTRACT}

Self-portraits using moko 'tattoo' have a relatively short history (1815-1884) within Māori culture, yet they provide many revelations about Māori and how they saw themselves. These took two forms: those which were made on land deeds across the country, and those made on request for Europeans. Examples range from a letter to King William IV in 1831 signed by 13 Ngāpuhi chiefs, to a self-portrait by Te Peehi Kupe of Ngāti Toa Rangitira made in Liverpool, England and two drawings by Tuai of his Ngāre Raumati brother Korokoro. I argue here that these drawings should be read as part of a unique system of Māori self-portraiture in which the physiognomic details so critical in Western European traditions of self-portraiture are replaced by 
complex forms of moko. In doing so, they provide a snapshot into cross-cultural engagement and interaction between Māori and Pākehā, and suggest a deeper level of Māori understanding of such practices than previously thought. That these drawings are regarded as the ancestors by their descendants today is evidence of the enduring power of these tohu 'sign'.

Keywords: literacy, moko, Ngāpuhi, Ngāti Toa, Rangatira, Ngāi Tahu, print, portraiture, self-portraiture, Māori, tattoo, New Zealand

\section{CITATION AND AUTHOR CONTACT DETAILS}

Ellis, ${ }^{1}$ Ngārino 2014. Ki tō ringa ki ngā rākau à te Pākehā? Drawings and signatures of moko by Māori in the early 19th century. Journal of the Polynesian Society 123 (1): 29-66; DOI: http://dx.doi.org/10.15286/jps.123.1.29-66

${ }^{1}$ Corresponding author: Art History, University of Auckland, Private Bag 92019, Auckland, New Zealand 1142; email address: ngarino.ellis@auckland.ac.nz 